\title{
Cassava Flour: Quantification of Cyanide Content
}

\author{
André Rinaldi Fukushima1,2,3, Maria Aparecida Nicoletti ${ }^{3,4}$, Almir Junior Rodrigues ${ }^{1}$, \\ Caroline Pressutti ${ }^{1}$, Jeandro Almeida ${ }^{1}$, Tamires Brandão ${ }^{1}$, Rosilene Kinue Ito ${ }^{3}$, \\ Luis Antônio Bafille Leoni', Helenice De Souza Spinosa ${ }^{2}$ \\ ${ }^{1}$ USJT-Pharmacy Course, Universidade São Judas Tadeu, Campus Capital, São Paulo, Brazil \\ ${ }^{2}$ FMVZ-School of Veterinary Medicine and Animal Science, Universidade de São Paulo, Campus Capital, São \\ Paulo, Brazil \\ ${ }^{3}$ Pharmacy Course, Universidade Guarulhos-Ser Educacional, Campus Centro, São Paulo, Brazi \\ ${ }^{4}$ Departamento de Farmácia, Faculdade de Ciências Farmacêuticas, Universidade de São Paulo, \\ Campus Capital, São Paulo, Brazil \\ Email: nicoletti@usp.br
}

Received 14 April 2016; accepted 20 June 2016; published 23 June 2016

Copyright (C) 2016 by authors and Scientific Research Publishing Inc.

This work is licensed under the Creative Commons Attribution International License (CC BY). http://creativecommons.org/licenses/by/4.0/

(c) (i) Open Access

\begin{abstract}
Cassava flours are obtained from the roots of Manihot esculenta Crantz and daily fairly consumed by the Brazilian population considering it comes to hum food, and also inserted into food baskets, besides to present low cost and easy access, in addition to being plant easily cultivated by the population. However, the food obtained with cassava may contain hydrocyanic acid, in the form of cyanogenic glycoside when those meals are not cooked properly. The oral toxicity can range 30 - 210 $\mathrm{mg} / \mathrm{kg}$ body, the average daily consumption per capita in larger rural areas than in urban areas for cassava flour $19.1 \mathrm{~g}$ against $4.7 \mathrm{~g}$, respectively. Brazil's North and Northeast have higher consumption of cassava flour, associated with family monthly monetary income, making this region more vulnerable to poisoning. The objective of this study was to quantify cyanogenic glycosides present in some types of Brazilian cassava foods by means of spectrophotometric technique (reading at a wavelength of $530 \mathrm{~nm}$ ). For quantitative determination of cyanide content, linamarase hydrolysis was used. The amount of cyanide was determined, and results were: artisan toasted cassava flour: $15 \mathrm{mg} / 500 \mathrm{~g}$, sweet cassava starch: $32.5 \mathrm{mg} / 500 \mathrm{~g}$, artisan dried cassava flour: $37.5 \mathrm{mg} / 500 \mathrm{~g}$, "bijuzada" cassava flour: $60 \mathrm{mg} / 500 \mathrm{~g}$, industrialized, toasted cassava flour: $115 \mathrm{mg} / 500 \mathrm{~g}$, industrialized, raw cassava flour: $140 \mathrm{mg} / 500 \mathrm{~g}$, and wet cassava flour: $225 \mathrm{mg} / 500 \mathrm{~g}$. Considering the chronic ingestion of cyanide present in these foods, they can cause public health problems.
\end{abstract}

\section{Keywords}

Manihot esculenta Crantz, Manihot, Flour, Cyanides, Toxicity, Spectrophotometry, Konigi Method 


\section{Introduction}

Manihot esculenta Crantz, commonly known as cassava, is a plant belonging to the class Malpighiales, Family Euphorbiceae, and genus Manihot. It is a plant of great economic interest, mainly in developing countries, as it has an important role as human food. Brazil is the second greatest world producer among 100 countries that grow cassava, and is responsible for $10 \%$ of the world production. Cassava is grown in all Brazilian regions, and it is used as raw material for cassava products [1].

From the 98 known species of the family Euphorbiceae, cassava is the only one that is grown as food [2]. Cassava roots are energetic foods, presenting high levels of carbohydrates, mainly polysaccharides. In general, cassava has an average composition of $68.2 \%$ moisture, $30.0 \%$ starch, $2.0 \%$ ash, $1.3 \%$ protein, $0.2 \%$ fat, and $0.3 \%$ fiber [3].

Cassava species are classified in two groups, according to the difference in toxicity and palatability of the roots: sweet (slightly sweet; that is, plants that have less than $100 \mathrm{mg} / \mathrm{kg}$ cyanuric acid) or bitter (those that have a perceptible bitter taste due to the high concentrations of HCN, that is, values over $100 \mathrm{mg}$ ). There is no morphological characteristic that may tell these two groups apart [4]-[8].

The most concrete difference between the sweet and bitter varieties is the type of use. Bitter cassava is used for flour, starch production, and other uses, but only after some type of detoxifying industrial process. Sweet varieties are more versatile, and may be processed similarly to bitter varieties, but they are also consumed after simpler preparations, such as boiling, frying, or roasting [9].

Cassava belongs to the group of cyanogenic plants as it has cyanogenic glycosides and enzymes distributed in its roots and leaves in different concentrations. Cyanide (the chemical product that has a cyanide group- $\mathrm{C} \equiv \mathrm{N}$ ) leads to toxic acute and chronic effects on biological systems. When the cells of the cassava roots are ruptured, the enzyme linamarase degrades cyanide, releasing cyanuric acid (HCN), which is extremely toxic both to humans and animals [10].

The oral route is the main path of exposure to cyanuric acid, and occurs by means of unintentional ingestion. However, inhalation is also common, especially during cassava processing. According to the World Health Organization (WHO), the currently determined lowest lethal dose that kills $50 \%$ of the animals of a study (LD $\left.\mathrm{L}_{50}\right)$ is $10 \mathrm{mg} / \mathrm{kg}$ (by inhalation) [11] [12]. In another study, it was demonstrated that the oral dose of cassava extracted linamarin was $324.86 \mathrm{mg} / \mathrm{kg}$ by oral route [13]. Another study determined a concentration range with lethal doses for humans between 30 and $210 \mathrm{mg} / \mathrm{kg}$ of live weight [14].

As cassava is a highly important food that may be easily grown in the most different parts of the country, and considering that Brazilian feeding habits involve cassava in different forms, such as flours; and that both chronic and acute ingestion may cause several diseases in men and animals, the objective of this study is to quantify cyanogenic glycosides found in different types of commercially available cassava flours.

\section{Material and Methods}

Commercial samples of cassava products used in the study were purchased in different retail stores in the city of São Paulo, SP. Three packages of each of the following types of cassava flour were purchased: artisan toasted cassava flour; sweet cassava starch; artisanal dried cassava flour; "bijuzada” cassava flour; industrialized, toasted cassava flour; industrialized, raw cassava flour; and wet cassava flour. In the laboratory, these packages were opened, and $1 \mathrm{~g}$ was used in the chemical analyzes (Figures 1-3).

\subsection{Equipment}

Shimadzu ${ }^{\circledR}$ visible spectrophotometer model UV mini 1240 (the equipment gives digital results through showing the sample absorvance value on the equipment visor), analytical scale Gehaka ${ }^{\circledR}$, Fisatom ${ }^{\circledR}$ magnetic stirrer, digital pHmeter Gehaka $^{\circledR}$ PG 2000, Fanem ${ }^{\circledR}$ test tube centrifuge Model 206 BL, $-20^{\circ} \mathrm{C}_{\text {Freezer Consul }}{ }^{\circledR}$, Fanem ${ }^{\circledR}$ incu- $^{\circ}$ bator Model 311 CG, Quimis ${ }^{\circledR}$ water bath model Q215M were used in the study.

\subsection{Methods}

The spectrophotometry technique used, also known as Konigi method, is based on picric acid and on the reduction of sodium picrate by cyanide forming a color compound that may be read at $530 \mathrm{~nm}$ wave-length. This method has a lower limit of detection of $1 \mathrm{mg} \cdot \mathrm{L}^{-1}$ cyanide, with $2 \%$ deviation, showing stable color that is resistant to other components [15]. 


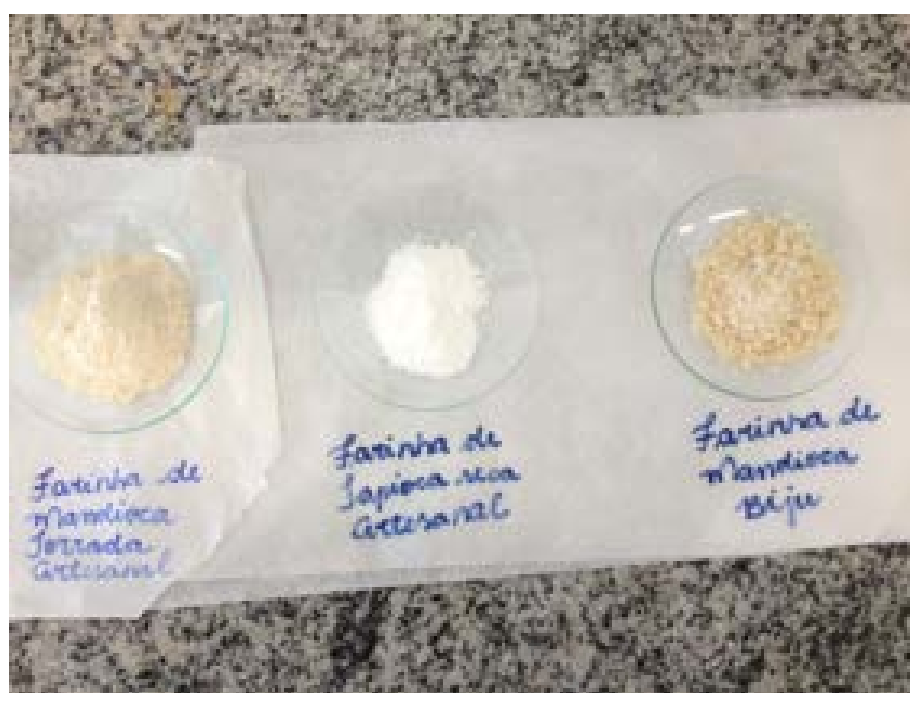

Figure 1. (from left to right) Artisan toasted cassava flour, artisanal dried cassava flour and "bijuzada” cassava flour.

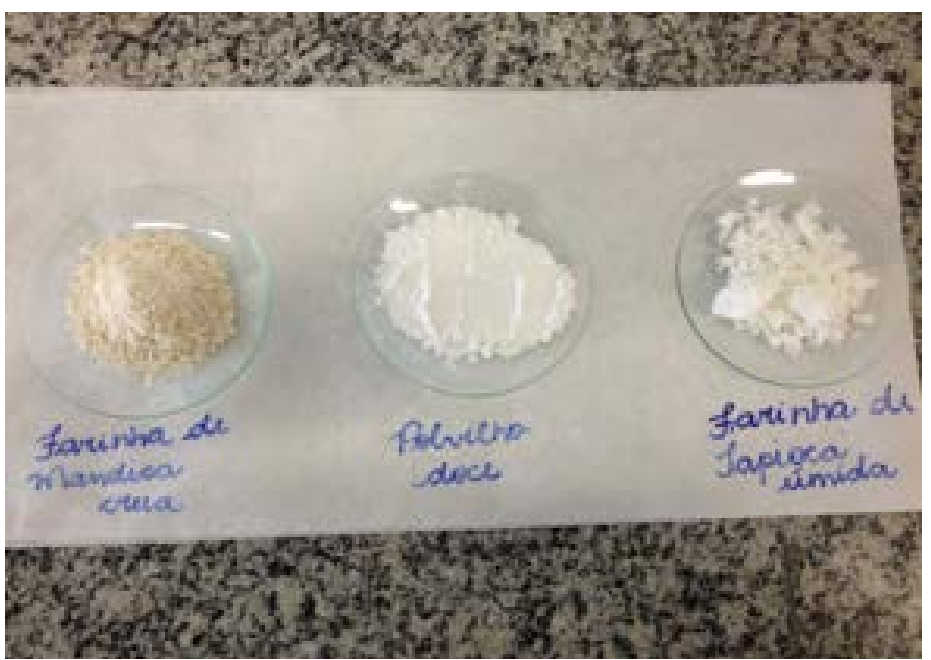

Figure 2. (from left to right) Raw cassava flour; sweet cassava starch and wet cassava flour.

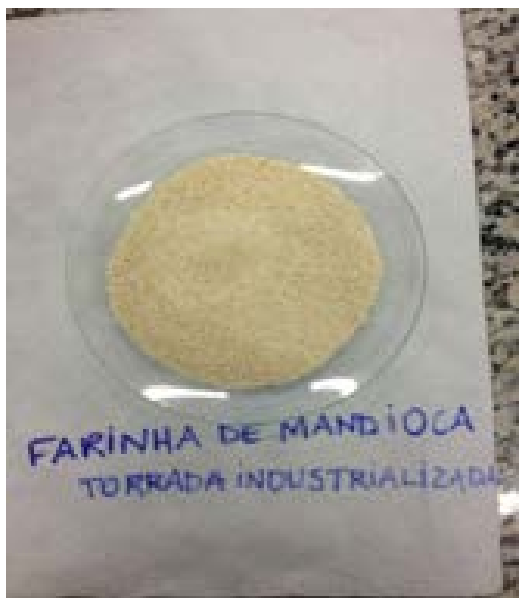

Figure 3. Industrialized, toasted cassava flour. 
Cyanide quantification was performed by drawing a calibration curve, using the validation parameters described in Resolution RE no. 899 [16]. Analyses were carried out with four analysts in three non-consecutive days. The variation coefficient between analysts and the mean cyanide content in the three samples of the different kinds of flour were calculated.

\section{Results}

Variation coefficient observed between the analysts was $0.998 \%$.

The calibration curve (Figure 4) was determined for the evaluation of the correlation coefficient (0.9982) and determination of the equation of the straight line $(y=0.0002+0.001)$.

The results obtained in the correlation coefficient were satisfactory for the method employed in the quantification of cyanide in the samples.

Results of cyanide quantification in the samples analyzed are shown in Table 1.

Among the different types of cassava flour analyzed, wet cassava flour showed the higher concentration of cyanide $(225 \mathrm{mg} / 500 \mathrm{~g})$. This fact may be attributable to the moisture, once most of the glucosides able to generate cyanide, such as linamarin and lotaustralin, are soluble in water, and keeping the product in water prevents the elimination of the toxic products.

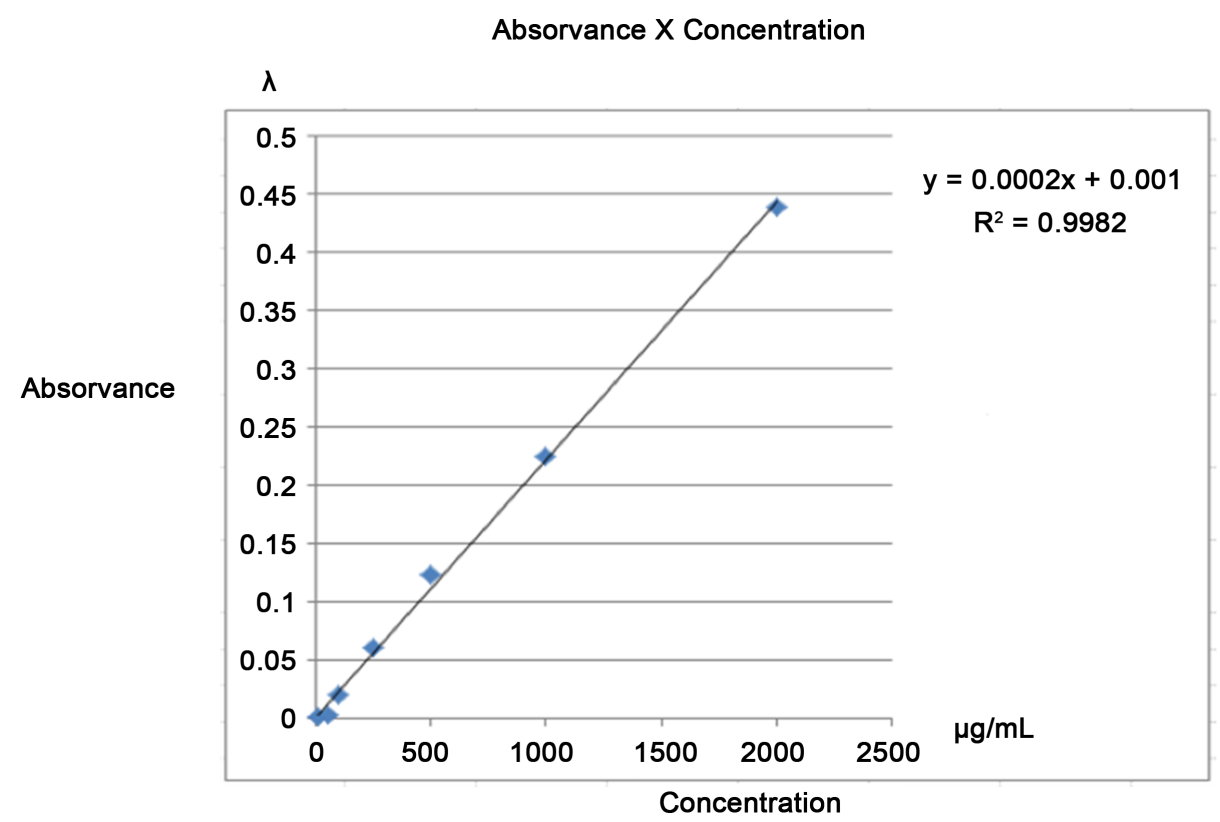

Figure 4. Calibration curve.

Table 1. Cyanide content per gram of cassava flour or starch.

\begin{tabular}{|ccc}
\hline Cassava flour and starch samples & $\begin{array}{c}\text { Standard } \\
\text { deviations }\end{array}$ & $\begin{array}{c}\text { Cyanide } \\
\text { concentration (mg/500g) }\end{array}$ \\
\hline $\begin{array}{c}\text { Artisan toasted cassava flour } \\
\text { Sweet cassava starch }\end{array}$ & $\mathbf{0 . 0 6 4 2 9 0 1}$ & 15 \\
\hline $\begin{array}{c}\text { (starchy cassava product classified as sweet or sour according to its acidity) } \\
\text { Artisanal dried cassava flour } \\
\text { "Bijuzada" cassava flour }\end{array}$ & 0.141421 & 32.5 \\
Industrialized, toasted cassava flour & 0.224231 & 37.5 \\
Industrialized, raw cassava flour & 0.360551 & 60 \\
Wet cassava flour & 0.3511884 & 115 \\
\hline
\end{tabular}


In this sense, the quantification of total cyanide in the different processing stages of wet and dry cassava flours showed that the wet flower showed lower levels of cyanide, and that the manufacturing process to produce these flours is effective in cassava cyanide detoxification.

On the other hand, artisan toasted cassava flour showed the lowest cyanide content (15 mg/500g) [10]. This finding evidences the importance of heat treatment to reduce cyanide content. The same finding was observed in industrialized, toasted cassava flour, which showed lower cyanide content (115 mg/500g) compared with industrialized, toasted cassava flour $(140 \mathrm{mg} / 500 \mathrm{~g})$.

Results obtained in this study show the importance of quantifying cyanide content in cassava, as well as the need for official regulations that determine safe levels of exposure to cyanide in foods, in order to ensure the quality of the final product, preventing risks to consumer health.

\section{Discussion}

Cassava consumption may be a risk factor for goiter, especially in regions where there is low iodine intake. Thiocyanate, a cyanide metabolite, changes thyroid metabolism, making iodine retention difficult. Therefore, goiter occurs mainly due to iodine deficiency, and may become more severe because of to the ingestion of glucosides [17]-[19].

Protein deficiency associated with a diet rich in foods that contain cyanogenic glucosides may lead to neurological damage due to the deficiency in sulfureted amino acids, leading to the accumulation of cyanide in the body [17] [20].

There are studies that correlate cassava intake with the onset of fibrocalculous pancreatic diabetes, which is considered to be a subclass of a new clinical type of diabetes that is related to inadequate nutrition [21] [22]. Besides, studies carried out in animals evidence that prolonged ingestion of cyanide is associated with hepatic and renal lesions in rabbits [18] [23] [24].

Chronic cyanide intoxication may lead to several consequences to humans, such as Tropical Ataxic Neuropathy (TAN), a syndrome involving myelopathy, bilateral optic atrophy, bilateral deafness, and polyneuropathy, which is observed in some areas of Nigeria and Tanzania. Other severe health problems that may be found together with TAN are Parkinson's disease, cerebellar degeneration, psychoses, and dementia [17] [20].

Cyanogenic glucosides are organic compounds made up of sugar and anaglycone (no sugar). They are formed, in general, by a hemiacetal bind between reduced sugar groups and the aglyconephenolic hydroxyl. The aglyconeportion of these cyanogenic compounds may be made up by an alquil, aril/alquil, or aril group which, generally, defines the characteristics of the glucoside. Therefore, when this group is represented by hydroxynitriles (cyanohydrin), it may be classified as cyanogenic [25] [26].

There are factors that influence the concentration of cyanogenic glucosides in plants, such as age, and seasonal, environmental, nutritional, and genetic factors [27].

Cassava accumulates two glucosides in its roots and leaves: linamarin and lotaustralin (93:7 ratios). These glucosides are able to produce cyanuric acid by hydrolysis. The enzyme responsible for the hydrolysis is linamarase; when the plant tissue is hydrolyzed/degraded, linamarin gets in contact with this enzyme, and when it is broken down, it yields glycose and $\alpha$-hydroxynitriles, which, when catalyzed by a hydroxynitrillyase, yields cyanuric acid and ketones [28]. As linamarindoes not accumulate, $\mathrm{LD}_{50}$ is not reached. Therefore, animals recover. There is no mention to this compound in Brazilian official regulations [12].

Glucosides are easily hydrolyzed and degradation products are sugar and cyanohydrin, which, in its turn, yields the toxic compound cyanuric acid. Several factors are associated with hydrolysis, such as acid $\mathrm{pH}$, endogenous enzymes, or even the action of beta-glucosidases found in foods that are eaten at the same time [27] [29].

Plant that have more than $20 \mathrm{mg}$ of cyanide in $100 \mathrm{~g}$ are considered of high risk for intoxication, even when ingested in small amounts. Cyanide is found in larger concentrations in the leaves of these plants. However, it may also be found, in considerable amounts, in roots, seeds, and other parts of the plant [30] [31].

As cassava is a product used as human food and animal feed, cassava products are subjected to a series of health regulations, such as:

Brazilian Ministry of Agriculture (MAPA) regulation no. 554, from August $30^{\text {th }}$, 1995, which approves the standard for identity, quality, storage, and transport of cassava flour to be commercialized, determining new specifications for cassava flour classification [32].

Collegiate Directory Resolution (RDC) no. 359, from December $23^{\text {rd }}, 2003$, which approves the technical regulation national labels in portions of packaged food [33]. 
Collegiate Directory Resolution (RDC) no. 263, from September $22^{\text {nd }}, 2005$, which approves the technical regulation for cereals, starches, flours and meals [34].

As cassava flour is an industrialized product, it is inferred that it undergoes processes that would eliminate most cyanide found in the original product. However, residues may be found in amounts that are sufficient to lead to signs of intoxication [28].

According Naves et al. consumption of significant cyanide doses arising from foods rich in cyanogenic glycosides and poorly processed may result in acute and chronic poisoning, causing abnormalities such as Konzo disease (disease found in Africa that causes paralysis of the legs. This disease arises especially in poor rural areas and affects mainly young women and children and causes paralysis of the legs). Cyanide also features remarkable toxic power because it is a potent inhibitor of cytochrome oxidase, which results in blocking the electron transport chain during cellular respiration process. It is estimated that the consumption of food containing hydrocyanic acid (HCN) in a concentration between 0.5 to $3.5 \mathrm{mg}$ of HCN per kg body weight, may cause the individual to death within minutes. However, the risk of intoxication can be minimized from the use of preparation processes, such as baking, frying and drying to reduce the content of such a compound in food. This beneficial effect results from the removal of cyanogenic glycosides, the inactivation of $\beta$-glucosidase, or both [35].

\section{Conclusions}

Cassava and its products are widely used in Brazil (and also, in other countries), being part of daily feeding habits in different Brazilian regions. Although cassava products are industrially processed, there is no official standard for the maximum amount of $\mathrm{CN}^{-}$residues in these products, or established limits for safe human and animal intake.

Besides, there is an inherent occupational risk for operators working directly with the raw material, and, therefore, exposed to the toxic compounds discussed here. There also is an environmental risk posed by residues generated in the industrial process, with negative effects in animal health.

Industrial development has to be followed by the determination of standards for the consumer, environment, and workers to be safe when in contact with and when using these products. It should be emphasized that this food production segment is related with regional habits, which make it difficult, but not impossible, to update regulations related to this product, considering the impact these products may cause, as its effects are not clearly defined.

\section{References}

[1] Embrapa-Centro Nacional de Pesquisa de Mandioca e Fruticultura. Mandioca. https://www.embrapa.br/mandioca-e-fruticultura/cultivos/mandioca

[2] Carvalho, L.J.C.B. (2005) Biodiversidade e biotecnologia em mandioca (Manihot esculenta Crants). Anais doXI Congresso Brasileiro de Mandioca, Embrapa, Campo Grande. http://terere.cpao.embrapa.br/11cbm/_html/palestras/arquivoPDF/palestra_003.PDF

[3] Albuquerque, T.T.O., Miranda, L.C.G., Salim, J., Teles, F.F.F. and Quirino, J.G. (1993) Composição centesimal da raiz de 10 variedades de mandioca (Manihot esculenta Crantz) cultivadas em Minas Gerais. Revista Brasileira de Mandioca, 12, 7-12.

[4] Mühlen, G.S., Colombo, C.A. and Valle, T.L. (2001) Mandioca brava e aipim: diferenciação genética. In: Anais do Congresso Brasileiro de Melhoramento de Plantas, Vol. 1, CD-ROM, Goiânia.

[5] Pereira, A.S. and Pinto, M.G. (1962) Determinação da toxicidade da mandioca pelo paladar das raízes “in natura”. Bragantia, 21, CXLV-CL.

[6] Pereira, A.S., Nery, J.P. and Igue, T. (1965) Seleção de novos clones de mandioca para mesa, pela toxicidade e paladar de suas raízes “in natura”. Bragantia, 24, LV-LVIII.

[7] Dufour, D.L. (1988) Cyanide Content of Cassava (Manihot esculenta, Euphorbiaceae) Cultivars Used by Tukanoan Indians in Northwest Amazonia. Economic Botany, 42, 255-266. http://dx.doi.org/10.1007/BF02858929

[8] Lorenzi, J.O., Ramos, M.T.B., Monteiro, D.A., Valle, T.L. and Godoy Junior, G. (1993) Teor de ácido cianídrico em variedades de mandioca cultivadas em quintais do Estado de São Paulo. Bragantia, 52, 1-5.

[9] Valle, T.L., Carvalho, C.R.L., Ramos, M.T.B., Mühlen, G.S. and Villela, O.V. (2004) Conteúdo cianogênico em progênies de mandioca originadas do cruzamento de variedades mansas e bravas. Bragantia, 63, 221-226. http://www.scielo.br/scielo.php?script=sci_arttext\&pid=S0006-87052004000200007 
[10] Chisté, R.C. and Cohen, K.O. (2006) Estudo do processo de fabricação da farinha de mandioca. Documentos 267, Embrapa Amazônia Oriental, Belém, 75 p.

[11] Cumbana, A., Mirionee, E., Cliff, J. and Bradbury, H. 2007. (2007) Reduction of Cyanide Content of Cassava Flour in Mozambique by the Wetting Method. Food Chemistry, 101, 894-897. http://dx.doi.org/10.1016/j.foodchem.2006.02.062

[12] Cereda, M.P. and Lopes, A.M. (2003) Determinação do potencial de intoxicação em ratos, de linamarina extraída da mandioca. In: Faculdade de Engenharia de Alimentos da Unicamp, Ed., V Simpósio Latino-Americano de Ciência de Alimentos, Universidade Estadual de Campinas, Campinas.

[13] Cereda, M.P. (2002) Processamento da mandioca como mecanismo de detoxificação. In: Cereda, M.P., Coord., Tecnologia, usos e potencialidades de tuberosas amiláceas Latino Americanas, Fundação Cargill, São Paulo, 47-80.

[14] Gomes, P.T.C. (2010) Avaliação de características nutricionais da mandioca e de seus híbridos interespecíficos. Dissertação de Mestrado, Universidade de Brasília, Brasília.

[15] Oliveira, F.A. and Oliveira, F.C. (2010) Toxicologia experimental de alimentos. Editora Sulina, Porto Alegre.

[16] Brasil Agência Nacional de Vigilância Sanitária (2003) Resolução RE No 899, que determina a publicação do “Guia para validação de métodos analíticos e bioanalíticos” de 29 de maio de 2003. Diário Oficial da União, Poder Executivo. http://portal.anvisa.gov.br

[17] Oke, O.L. (1980) Toxicity of Cyanogenic Glycosides. Food Chemistry, 6, 97-109. http://dx.doi.org/10.1016/0308-8146(80)90025-4

[18] Kaneko, J.J. (1989) Thyroid Function. In: Kaneko, J.J., Ed., Clinical Biochemistry of Domestic Animals, 4th Edition, Academic Press, San Diego, 630-649.

[19] Delange, F.M. and Ermans, A.M. (1996) Iodine Deficiency. In: Braverman, L.E. and Utiger, R.D., Eds., Werner and Ingbar's the Thyroid: A Fundamental and Clinical Text, 7th Edition, Lippincott-Raven, Philadelphia, 296-316.

[20] Montgomery, R.D. (1980) Cyanogens. In: Liener, I.E., Ed., Toxic Constituents of Plant Foodstuffs, Academic Press, New York, 143-160.

[21] Soto-Blanco, B., Gorniak, S.L. and Kimura, E.T. (2001) Physiopathological Effects of the Administration of Chronic Cyanide to Growing Goats-A Model for Ingestion of Cyanogenic Plants. Veterinary Research Communications, 25, 379-389. http://dx.doi.org/10.1023/A:1010694710124

[22] FAO Corporate Document Repository (2004) A Review of Cassava in Latin America and the Caribbean with Countries: Case Studies on Brazil and Colombia. Agricultural Department. http://www.fao.org/docrep/007/y5271e/y5271e07.htm

[23] Sousa, A.B., Soto-Blanco, B., Guerra, J.L., Kimura, E.T. and Górniak, S.L. (2002) Does Prolonged Oral Exposure to Cyanide Promote Hepatotoxicity and Nephrotoxicity? Toxicology, 174, 87-95. http://dx.doi.org/10.1016/S0300-483X(02)00041-0

[24] Okolie, N.P. and Osagie, A.U. (1999) Liver and Kidney Lesions and Associated Enzyme Changes Induced in Rabbits by Chronic Cyanide Exposure. Food and Chemical Toxicology, 37, 745-750. http://dx.doi.org/10.1016/S0278-6915(99)00059-9

[25] Owerend, W.G. (1972) Glycosides. In: Pigman, W. and Hortond, D., Eds., The Carbohydrates: Chemistry and Biochemistry, Academic Press, New York, 279-353. http://dx.doi.org/10.1016/B978-0-12-556301-7.50017-X

[26] Miller, L.P. (1973) Glycosides. In: Miller, L.P., Ed., Phytochemistry, Vol. 1, Van Nostrand Reinhold Company, New York, 297-375.

[27] Cutolo, P.T.M. (2015) Estudo dos agentes tóxicos naturalmente presentes em alimentos: Glicosídeos cianogênicos e glicosinolatos. [Trabalho de Conclusão de Curso—Graduação]. Universidade Estadual de Campinas, Faculdade de Ciências Aplicadas, Campinas, 29 p.

[28] Cagnon, J.R., Cereda, M.P. and Pantarotto, S. (2002) Série: Cultura de tuberosas amiláceas latino-americanas, Vol. 2-Cultura de tuberosas amiláceas latino-americanas. Fundação Cargill, In CD-ROM.

[29] Conn, E.E. (1979) Cyanide and Cyanogenic Glycosides. In: Rosenthal, G.A. and Janzen, D.H., Eds., Herbivores: Their Interaction with Secondary Plant Metabolites, Academic Press, New York, 387-410.

[30] Liener, I.E. (1969) Toxic Constituents of Plant Foodstuffs. Academic Press, New York.

[31] Silva, M.C. (2008) Caracterização parcial da lectina de folhas de mandioca (Manihot esculenta Crantz). Dissertação de Mestrado em Agroquímica, Universidade Federal de Lavras, Minas Gerais, 66 p.

[32] Brasil (1995) Portaria $n^{\circ}$ 554, de 30 de agosto de 1995. Norma de identidade, qualidade, apresentação, embalagem, armazenamento e transporte da farinha de mandioca. Diário Oficial da República Federativa do Brasil, Brasília DF.

[33] Brasil ANVISA-Agência Nacional de Vigilância Sanitária (2003) Resolução da Diretoria Colegiada (RDC) nº 359, 23 de dezembro de 2003. Aprova Regulamento Técnico de Porções de Alimentos Embaladospara Fins de Rotulagem Nutricional. http://portal.anvisa.gov.br 
[34] Brasil ANVISA-Agência Nacional de Vigilância Sanitária (2005) Resolução da Diretoria Colegiada (RDC) $n^{\circ} 262$, de 22 de setembro de 2005. Aprova o Regulamento Técnico para Produtos de Cereais, amidos, farinhas e farelos. http://portal.anvisa.gov.br

[35] Helbig, E. and Gigante, D.P. (2008) Análise dos teores de ácidos cianídrico e fítico em suplemento alimentar: Multimistura. Revista de Nutrição, 21, 323-328. http://dx.doi.org/10.1590/S1415-52732008000300007 